\title{
Growth and growth boundary model with terms for melting salts to predict growth responses of Listeria monocytogenes in spreadable processed cheese
}

Martinez Rios, Veronica; Jørgensen, Marie Østergaard; Koukou, loulia; Gkogka, Elissavet; Dalgaard, Paw

Published in:

Food Microbiology

Link to article, DOI:

10.1016/j.fm.2019.103255

Publication date:

2019

Document Version

Peer reviewed version

Link back to DTU Orbit

Citation (APA):

Martinez Rios, V., Jørgensen, M. Ø., Koukou, I., Gkogka, E., \& Dalgaard, P. (2019). Growth and growth boundary model with terms for melting salts to predict growth responses of Listeria monocytogenes in spreadable processed cheese. Food Microbiology, 84, [103255]. https://doi.org/10.1016/j.fm.2019.103255

\section{General rights}

Copyright and moral rights for the publications made accessible in the public portal are retained by the authors and/or other copyright owners and it is a condition of accessing publications that users recognise and abide by the legal requirements associated with these rights.

- Users may download and print one copy of any publication from the public portal for the purpose of private study or research.

- You may not further distribute the material or use it for any profit-making activity or commercial gain

- You may freely distribute the URL identifying the publication in the public portal 


\section{Accepted Manuscript}

Growth and growth boundary model with terms for melting salts to predict growth responses of Listeria monocytogenes in spreadable processed cheese

Veronica Martinez-Rios, Marie Østergaard Jørgensen, Ioulia Koukou, Elissavet Gkogka, Paw Dalgaard

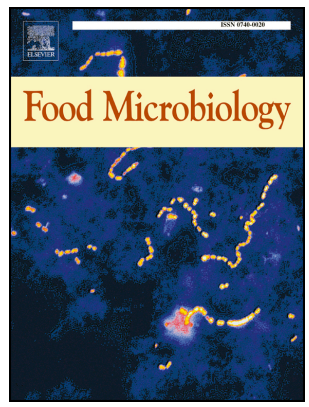

PII: S0740-0020(19)30291-6

DOI: https://doi.org/10.1016/j.fm.2019.103255

Article Number: 103255

Reference: $\quad$ YFMIC 103255

To appear in: Food Microbiology

Received Date: 23 March 2019

Revised Date: 25 June 2019

Accepted Date: 28 June 2019

Please cite this article as: Martinez-Rios, V., Jørgensen, Marie.Ø., Koukou, I., Gkogka, E., Dalgaard, P., Growth and growth boundary model with terms for melting salts to predict growth responses of Listeria monocytogenes in spreadable processed cheese, Food Microbiology (2019), doi: https:// doi.org/10.1016/j.fm.2019.103255.

This is a PDF file of an unedited manuscript that has been accepted for publication. As a service to our customers we are providing this early version of the manuscript. The manuscript will undergo copyediting, typesetting, and review of the resulting proof before it is published in its final form. Please note that during the production process errors may be discovered which could affect the content, and all legal disclaimers that apply to the journal pertain. 
2 Growth and growth boundary model with terms for melting salts to predict growth responses of

$3 \quad$ Listeria monocytogenes in spreadable processed cheese

4

5 Veronica Martinez-Rios ${ }^{1}$, Marie $\emptyset_{\text {stergaard Jørgensen }}{ }^{1,3}$, Ioulia Koukou ${ }^{1}$, Elissavet Gkogka ${ }^{2}$, Paw 6 Dalgaard $^{1}$

$8{ }^{1}$ National Food Institute (DTU Food), Technical University of Denmark, Kgs. Lyngby, Denmark

$9 \quad{ }^{2}$ Arla Innovation Centre, Arla Foods amba, Aarhus N, Denmark

10

* Corresponding author: Food Microbiology and Hygiene, National Food Institute, Technical

17 University of Denmark, Kemitorvet, Building 202, DK-2800, Kgs. Lyngby, Denmark. E-mail: veri@food.dtu.dk (V. Martinez-Rios)

19

${ }^{3}$ Present address: GEA group, Søborg, Denmark 


\section{ABSTRACT}

22 The aim of this study was to develop and validate a growth and growth boundary model with terms

23 for melting salts to predict growth of Listeria monocytogenes in spreadable processed cheese.

24 Cardinal parameter terms for phosphate salts and citric acid were developed in broth studies and used to expand an available growth and growth boundary model. The expanded model includes the effect of nine environmental factors (temperature, $\mathrm{pH}, \mathrm{a}_{\mathrm{w}}$, lactic acid, acetic acid, citric acid, orthophosphate, di-phosphate and tri-phosphate). To generate growth data for model evaluation challenge tests with inoculated commercial $(n=10)$ and customized $(n=10)$ spreadable processed cheeses were performed. Evaluation of the new model by comparison of observed and predicted $\mu_{\max }$-values resulted in a bias factor of 1.12 and an accuracy factor of $1.33(\mathrm{n}=42)$. Prediction of growth and no-growth responses in processed cheese $(n=60)$ were $89 \%$ correct with $11 \%$ fail-safe and $0 \%$ fail-dangerous predictions. The developed model can be used to support product development, reformulation or risk assessment for spreadable processed cheese.

Keywords: Phosphate salts, product development, risk assessment, predictive microbiology 


\section{Introduction}

Spreadable processed cheese is a ready-to-eat product manufactured by blending cheese, melting salts (e.g. sodium or potassium salts of phosphoric or citric acid) and other dairy and nondairy ingredients, followed by heating and mixing to obtain a uniform molten mass which is typically hot-filled into the final packaging (Fox et al., 2017). Formulation parameters for spreadable processed cheese may vary considerably in terms of $\mathrm{pH}$ (4.7-6.3), moisture (ca. 50-70\%) and salt content (Maurer, 2012; Kim et al., 2018). Food-grade hydrocolloids (e.g. carob bean gum, guar gum, xanthan gum, gelatine and/or carrageenan) can be used to influence product texture and to reduce the water activity of spreadable processed cheese (Guinee et al., 2004). Melting salts are ingredients known to contribute to the microbiological safety and stability of spreadable processed cheese, besides their main function as emulsifying agents. Among melting salts, phosphates are well known to inhibit the growth of spore-forming bacteria which are key microorganisms to control in processed cheeses (Tanaka et al., 1986; Tompkin, 1983). However, little information is available about their inhibitory effect against pathogens that may potentially contaminate the product during open shelf-life and especially under conditions of temperature abuse by the consumer.

Unsafe food handling by consumers, including cross-contamination and storage conditions, is believed to contribute significantly to foodborne illness (De Jong et al., 2008; Evans and Redmond, 2018; Redmond and Griffith, 2003). Based on data for several countries, more than one third of domestic refrigerators operate at temperatures above $5^{\circ} \mathrm{C}$ which is the maximum recommended chilled temperature for most ready-to-eat products (James et al., 2008; Roccato et al., 2017; WHO, 2006). Hygiene and temperature control can be critical in relation to food safety with EFSA estimates showing that prevention of growth of Listeria monocytogenes in ready-to-eat products at the consumer phase can reduce annual listeriosis cases in the Member States by $37 \%$ (EFSA, 2018). 

L. monocytogenes growth depending on product characteristics and different reasonably foreseeable storage conditions of ready-to-eat foods (EC, 2005). Melting salts are known to inhibit growth of foodborne pathogens such as Bacillus cereus, Clostridium botulinum and Staphylococcus aureus (ter Steeg et al., 1995a; Maier et al., 1999; Loessner et al., 1997). In the same way, melting salts may be important in controlling L. monocytogenes growth in spreadable processed cheeses but their anti-listerial effect remains little studied. The potential growth of L. monocytogenes e.g. after opening a hot-filled packaged food product can be evaluated by challenge tests or predictive mathematical modelling (EC, 2005). Application of validated predictive models is typically a faster and more cost effective approach but to accurately predict growth responses of L. monocytogenes mathematical models must include the effect of all important preserving factors (Mejlholm et al., 2010; Ross and Dalgaard, 2004). Many L. monocytogenes growth models are available, some including the inhibitory effect of several intrinsic along with extrinsic factors and a few models have been successfully validated for different types of dairy products (Augustin et al., 2005; Martinez-Rios et al. 2019; Mejlholm et al., 2010). However, none of the available $L$. monocytogenes growth models include the inhibitory effect of melting salts or have been successfully validated for spreadable processed cheeses.

The objective of the present study was to expand and validate a mathematical model to predict growth and growth boundary of L. monocytogenes in spreadable processed cheese including phosphate/citrate salts and/or organic acids. Firstly, the growth inhibiting effects of phosphate and citrate salts on L. monocytogenes were studied in broth and their minimum inhibitory concentrations (MICs) were determined. Secondly, new mathematical terms for the inhibiting effect of these compounds were included in the growth and growth boundary model of Mejlholm and Dalgaard 
84 (2009). Finally, the performance of the expanded model was evaluated by comparison of predicted

85

86

87

88

89

90

91

92

93 and observed growth for L. monocytogenes in spreadable processed cheese.

\section{Materials and methods}

2.1. Bacterial strains and pre-culture conditions

Four dairy related strains of L. monocytogenes were provided by Arla Foods amba and used as a cocktail (SLU 92, 612, LM19, 6) to determine $\mu_{\max }$-values in broth and for inoculation of challenge test. Prior to use, each strain was transferred from storage at $-80^{\circ} \mathrm{C}$ to Brain Heart Infusion (BHI) broth (CM1135, Oxoid, Hampshire, UK) and incubated for $24 \mathrm{~h}$ at $25^{\circ} \mathrm{C}$. Subsequently, for broth studies the individual strains were pre-cultured one day at $25^{\circ} \mathrm{C}$ in $\mathrm{BHI}$ broth with $\mathrm{pH} 6.2$ and $0.5 \% \mathrm{NaCl}$. For challenge testing the individual stains were pre-cultured one or two days at $8^{\circ} \mathrm{C}$ to $20^{\circ} \mathrm{C}$ in $\mathrm{BHI}$ broth with $\mathrm{pH} 6.2$ and $1 \% \mathrm{NaCl}$ to simulate temperature abuse conditions encountered in spreadable processed cheese during open-shelf life. Pre-cultures were grown to a relative increase in absorbance $(540 \mathrm{~nm}$ ) of 0.05 to 0.2 (Novaspec II, Pharmacia Biotech, Allerød, Denmark). The L. monocytogenes cocktail of strains (Lm-mix) used in broth and challenge test studies were produced by mixing equal volumes of individual pre-cultures. The cell concentration of $\mathrm{Lm}$-mix was determined by direct phase-contrast microscopy at $1000 \mathrm{x}$ magnification considering that one cell per field of view corresponded to a concentration around $10^{6}$ cfu/ml (Adams and Moss, 2016).

\subsection{Phosphate and citrate salts}


MICs were determined for three different phosphate salts and trisodium citrate.

2.3. Cardinal parameter values for phosphate and citrate salts

The inhibitory effect of eight to 17 different concentrations of P1 (0 to 6.5\%), P2 (0 to 6\%), P3 (0 to 5\%) and TC (0 to $9 \%$; corresponding to $0-137,000 \mathrm{ppm}$ of citric acid) on $\mathrm{Lm}$-mix were determined at $25^{\circ} \mathrm{C}$ in BHI-broth with $\mathrm{pH}$ 6.2. A total of $154 \mu_{m a x}$-values were determined. For each condition, growth of Lm-mix was determined in duplicate by using automated absorbance measurements at $540 \mathrm{~nm}$ (BioScreen C, Labsystems, Helsinki, Finland). Detection times, defined as incubation time necessary to observe an increase in absorbance of 0.05 from the lowest absorbance measured in the beginning of incubation, were determined for each absorbance growth curve. $\mu_{\max ^{-}}$ values of $L m$-mix were determined from absorbance detection times for serially diluted inoculation levels of $10^{2}, 10^{3}, 10^{4}, 10^{5}$ and $10^{6} \mathrm{cfu} / \mathrm{ml}$ as previously described (Dalgaard and Koutsoumanis, 2001). The cardinal parameter values for the different phosphate and citrate salts (P1, P2, P3 and TC) were estimated by fitting eq. (1) to square root transformed $\mu_{m a x}$-values of L. monocytogenes.

$$
\sqrt{\mu_{\max }}=\sqrt{\mu_{r e f_{25^{\circ} C} \cdot\left(1-\left(\frac{[P \text { or } T C]}{M I C_{P \text { or } T C}}\right)^{n 1}\right)^{n 2}}}
$$

where $[\mathrm{P}$ or TC] are the concentrations $(\%)$ of individual phosphates $(\mathrm{P} 1, \mathrm{P} 2, \mathrm{P} 3)$ or citrate salt $(\mathrm{TC})$ and $\mathrm{MIC}_{\mathrm{P} \text { or } \mathrm{TC}}$ is the fitted MIC-value (\%) of individual phosphates (P1, P2, P3) or citrate salt (TC) that prevents growth of L. monocytogenes. The cardinal parameter value for citric acid $\left(M I C_{U} C A C\right)$ was determined from concentrations of undissociated citric acid calculated by eq. (2) with a pKa 
value of 3.13 (Ross and Dalgaard, 2004) from concentrations of TC. The cardinal parameter value was estimated by fitting eq. (3) to square root transformed $\mu_{\max }$-values of $L m$-mix.

Undissociated organic acid $(m M)=\frac{\operatorname{Citric} \text { acid }(m M)}{1+10^{p H-p K_{a}}}$

$\sqrt{\mu_{\max }}=\sqrt{\mu_{r e f_{25^{\circ} C}} \cdot\left(1-\left(\frac{\left[C A C_{U}\right]}{M I C_{U} C A C}\right)^{n 1}\right)^{n 2}}$

where $\left[\mathrm{CAC}_{\mathrm{U}}\right]$ is the concentration $(\mathrm{mM})$ of undissociated citric acid and $M I C_{U} C A C$ is the fitted MIC-value of undissociated citric acid that prevents growth of $L$. monocytogenes. When fitting eq. (1 and 3), n1 was set to 0.5 or 1 and $n 2$ was set to 1 or 2 (Dalgaard, 2009) in order to describe data most appropriately and this was determined from root mean square error (RMSE) values.

\subsubsection{Growth inhibiting effect of interaction between phosphate and citrate salts}

The effect of interaction for different combinations of phosphate and citrate salts concentrations (P1: 0-6\%; P2: 0-5.5\%; P3: 0-5\%; TC: 0-8\%) on Lm-mix were determined in BHIbroth with pH 6.2 at $25^{\circ} \mathrm{C}$. A total of $66 \mu_{\max }$-values were generated experimentally as explained above (Section 2.3). Experiments were designed to include combinations of concentrations that were close to the growth boundary of L. monocytogenes.

\subsubsection{Anti-listerial effect of commercial melting salt preparations}

The inhibitory effect for different concentrations of DP (0 to 8.6\%), BUDAL (0 to $15.5 \%$ ), PZ6, PZ35, S9, PZ189 (0 to 4.5\%) and S9K (0 to 8\%) on $\mu_{\text {max }}$-values of $L m$-mix were determined.

A total of $94 \mu_{\max }$-values were generated in BHI-broth with pH 6.2 at $25^{\circ} \mathrm{C}$ (See 2.3). 
2.4. Development of a new L. monocytogenes growth and growth boundary model

New mathematical terms including MIC values for P1, P2, P3 and either TC or $C A C_{U}$ were added to an existing cardinal parameter growth and growth boundary model previously validated for growth of L. monocytogenes in some non-fermented dairy products (Mejlholm and Dalgaard, 2009; Mejlholm et al., 2010). Of the 12 environmental factors in that model, exclusively terms for the effect of temperature, $\mathrm{pH}, \mathrm{NaCl} / \mathrm{a}_{\mathrm{w}}$, lactic acid and acetic acid were used in the present study and included in a new L. monocytogenes growth and growth boundary model with terms for the inhibitory effect of phosphate salts and either citrate salt or undissociated citric acid (eq. 4). A recently developed cardinal parameter $p H_{m i n}$-function was used to estimate $p H_{m i n}$-values for $L$. monocytogenes depending on the storage temperature (Martinez-Rios et al., 2019).

$$
\begin{aligned}
& \mu_{\text {max }}=\mu_{\text {ref }} \cdot\left[\frac{(T+2.83)}{\left(T_{r e f}+2.83\right)}\right]^{2} \cdot \frac{\left(a_{w}-0.923\right)}{(1-0.923)} \cdot\left[1-10^{\left(p H_{\min }-p H\right]} \cdot\left(1-\frac{\left[L A C_{U}\right]}{3.79}\right) \cdot\left(1-\sqrt{\frac{\left[A A C_{U}\right]}{10.3}}\right)\right. \\
& {\left[\left(1-\left(\frac{\left[C A C_{U}\right]}{M I C_{U} C A C}\right)\right) \operatorname{or}\left(1-\left(\frac{[T C]}{\left[M I C_{T C}\right]}\right)^{n 1}\right)^{n 2}\right] \cdot\left(1-\left(\frac{[P 1]}{\left[M I C_{P 1}\right]}\right)^{n 1}\right)^{n 2} \cdot\left(1-\left(\frac{[P 2]}{\left[M I C_{P 2}\right]}\right)^{n 1}\right)^{n 2} \cdot} \\
& \left(1-\left(\frac{[P 3]}{\left[M I C_{P 3}\right]}\right)^{n 1}\right)^{n 2} \cdot \xi
\end{aligned}
$$

where $\mu_{r e f}$ is a fitted parameter with value equal to $\mu_{\max }$ at the reference temperature $\left(T_{r e f}\right)$ of $25^{\circ} \mathrm{C}$ when other environmental factors do not inhibit growth; $\mathrm{T}$ is the temperature $\left({ }^{\circ} \mathrm{C}\right)$ and $\mathrm{a}_{\mathrm{w}}$ is the water activity measured in the product (Supplementary Table S1). $\left[\mathrm{LAC}_{U}\right],\left[\mathrm{AAC}_{U}\right],[\mathrm{CAC}]$ are the concentrations $(\mathrm{mM})$ of undissociated lactic acid, acetic acid and citric acid in the water phase, respectively. [P1], [P2], [P3] and [TC] are the concentrations (\%) in water phase of orthophosphate, di-phosphate, tri-phosphate and trisodium citrate respectively. $\left[\mathrm{MIC}_{P 1}\right],\left[\mathrm{MIC}_{P 2}\right],\left[\mathrm{MIC}_{P 3}\right]$, and $\left[\mathrm{MIC}_{T C}\right]$ are the fitted MIC-values (\%, in the water phase) of orthophosphate, di-phosphate, tri- 
$179=\left\{\begin{array}{ccrl}1, & \psi & \leq 0.5 \\ 2(1-\psi), & 0.5 & <\psi<1 \\ 0, & \psi & \geq 1\end{array}\right.$

$$
\varphi T=\left[1-\sqrt{(T+2.83) /\left(T_{\text {ref }}+2.83\right)}\right]^{2}
$$

$$
\varphi a_{w}=\left[1-\sqrt{\left(a_{w}-0.923\right) /(1-0.923)}\right]^{2}
$$


$\varphi p H=\left[1-\sqrt{1-10^{\left(p H_{\min }-p H\right)}}\right]^{2}$

$186=\left[1-\left(\left(1-\sqrt{\left[L A C_{U}\right] / 3.79}\right) \cdot\left(1-\sqrt{\left[A A C_{U}\right] / 10.3}\right) \cdot\left(1-\left[C A C_{U}\right] / M I C_{U C A C}\right)\right)\right]^{2}$

$187 \varphi[\mathrm{P} 1] ; \varphi[\mathrm{P} 2] ; \varphi[\mathrm{P} 3] ; \varphi[\mathrm{TC}]$

$188=\left[1-\left(\left(1-\left(\frac{P \text { or } T C}{M I C_{P \text { or } T C}}\right)^{n 1}\right)^{n 2}\right)\right]^{2}$

$189 \quad \psi=\sum_{i} \frac{\varphi_{e_{i}}}{2 \prod_{j \neq i}\left(1-\varphi_{e_{i}}\right)}$

190 The inhibiting effect of organic acids on interaction with other environmental factors in eq. (6) was

191 modelled by multiplication of their effects as previously suggested (Coroller et al., 2005).

192

193

2.5. Challenge test with spreadable processed cheese

194

To generate data for model evaluation, growth of L. monocytogenes in spreadable processed 195 cheese was determined in 20 inoculated challenge tests including 60 growth/no-growth responses at 196 constant and dynamic storage temperatures (see section 2.6.). These included ten 197 batches/formulations of customized spreadable processed cheese and 4 batches of commercially 198 available spreadable processed cheese (Table 2). 
Ten customized spreadable processed cheese recipes were designed to evaluate the effect of phosphate salts, citrate salt and undissociated citric acid. The customized recipes were produced in the pilot plant at Arla Innovation Centre in Aarhus and transported on ice to DTU Food where they were stored upon arrival at $2^{\circ} \mathrm{C}$ for a maximum of $48 \mathrm{~h}$ until further studied. Individual batches of customized spreadable processed cheese were produced with $3 \%$ or $6 \%$ orthophosphate (P1), diphosphate (P2) or trisodium citrate (TC) and $2 \%$ or $5 \%$ tri-phosphate (P3). A commercially available emulsifying salt preparation (S9K) was used to produce spreadable processed cheese with two different concentrations (3\% or $6 \%$ ). Two commercial spreadable processed cheeses were obtained from a local supermarket. Product $\mathrm{pH}$ was measured with a PHM 250 Ion Analyzer (MetroLab $^{\mathrm{TM}}$, Radiometer, Copenhagen, Denmark) after $1 \mathrm{~h}$ stirring of a $5 \mathrm{~g}$ sample in $25 \mathrm{ml}$ of distilled water. $\mathrm{NaCl}$ was quantified by automated potentiometric titration (785 DMP Titrino, Metrohm, Hesisau, Switzerland) and $\mathrm{a}_{\mathrm{w}}$ was calculated from the concentration of $\mathrm{NaCl}$ in the water phase (\%WPS) according to the relation derived from Resnik and Chirife (1988) $\left(\mathrm{a}_{\mathrm{w}}=1-0.0052471\right.$ . \%WPS - $0.0002206 \cdot \% \mathrm{WPS}^{2}$ ). In addition $\mathrm{a}_{\mathrm{w}}$ was measured by a water activity meter (Aqua Lab model CX-2, Decagon devices Inc., Pullman, US) (Supplementary Table 1). The concentrations of lactic, acetic and citric acid were determined by HPLC using external standards for identification and quantification. In order to improve extraction, a centrifugation step was applied (Dalgaard and Jørgensen, 2000; Martinez-Rios et al., 2016). Phosphate and citrate salt concentrations were determined by Eurofins, New Orleans, USA (test method QA02S). Product characteristics were determined on three samples for each batch and data reported as average \pm standard deviation.

2.5.2. Inoculation, storage conditions and microbiological analysis 
Cheese was inoculated with $0.1 \%(\mathrm{v} / \mathrm{w})$ of $\mathrm{Lm}$-mix appropriately diluted in chilled saline water $(0.85 \% \mathrm{NaCl})$ to obtain an initial concentration in the range of $1-3 \mathrm{Log} \mathrm{cfu} / \mathrm{g}$. Following inoculation, $50 \pm 5 \mathrm{~g}$ of cheese was placed in containers similar to those used for commercial distribution of the product. Samples were stored at 5, 10, 15 and $22^{\circ} \mathrm{C}$ or under dynamic temperatures (Table 2). Storage temperature was recorded every 30 minutes by data loggers (TinytagPlus, Gemini Data Loggers Ldt., Chichester, UK). Storage time was from 8 to 83 days for different treatments with 7 to 27 sampling times per treatment.

At each time of sampling a container with $50 \pm 5 \mathrm{~g}$ of cheese was analysed and then discarded. $10 \mathrm{~g}$ of cheese was diluted 10-fold in chilled physiological saline water with peptone $\left(0.85 \% \mathrm{NaCl}, 0.1 \%\right.$ Bacto $^{\mathrm{TM}}$ Peptone, 211677, BD Bioscience, San Jose, USA) and subsequently homogenized for 30s at normal speed in a stomacher (Stomacher 400 Circulator, Seward Medical, London, UK). Viable counts of L. monocytogenes were determined by surface plating on Palcam agar base (CM0877, Oxoid, Basingstoke, UK) with selective supplement (SR0150, Oxoid) and incubated at $37^{\circ} \mathrm{C}$ for $48 \mathrm{~h}$.

\subsubsection{Primary growth model}

The integrated and log transformed logistic model with delay (four parameter model) or without delay (three parameter model) (eq. (8); Rosso et al., 1996) was fitted to all individual growth curves of L. monocytogenes obtained in challenge tests at constant temperatures. Fitted parameter values for initial cell concentration $\left(\log N_{0}, \log \mathrm{cfu} / \mathrm{g}\right)$, lag time $\left(t_{\text {lag }}, \mathrm{h}\right)$, maximum specific growth rate $\left(\mu_{\max }, 1 / \mathrm{h}\right)$ and maximum population density $\left(\log N_{\max }\right.$, Log cfu/g) were determined for each growth curve and data was reported as average \pm standard deviation for challenge tests (Table 2). An F-test was used to determine if the lag time was significant. 
$\log \left(N_{t}\right)=\log \left(\frac{N_{\max }}{1+\left(\left(\frac{N_{\max }}{N_{0}}\right)-1\right) \cdot \exp \left(-\mu_{\max } \cdot\left(t-t_{\text {lag }}\right)\right)}\right)$

where $\mathrm{t}$ is the storage time (h) and $N_{t}$ is the cell concentration $(\mathrm{cfu} / \mathrm{g})$ at time $\mathrm{t}$. Other parameters were indicated above.

The relative lag time $\left(R L T=t_{\text {lag }} \cdot \mu_{\max } / \ln (2)\right)($ Mellefont and Ross, 2003) was calculated for all growth curves of L. monocytogenes in challenge tests (Table 2). It was evaluated if RLT-values were constant $\left(R L T=\mathrm{K}_{1}\right)$ or dependent on storage temperature $\left(R L T=\mathrm{K}_{1}+\mathrm{K}_{2} / \mathrm{T}^{2}\right)$ as reported by Hereu et al. (2014).

2.6. Evaluation of the new L. monocytogenes growth and growth boundary model

Comparison of observed and predicted $\mu_{\max }$-values was carried out by calculation of bias $\left(\mathrm{B}_{\mathrm{f}}\right)$ and accuracy $\left(\mathrm{A}_{\mathrm{f}}\right)$ factor values (Ross, 1996). For pathogenic bacteria, $0.95<\mathrm{B}_{\mathrm{f}}<1.11$ indicates a good model performance, with $\mathrm{B}_{\mathrm{f}} 1.11-1.43$ or $0.87-0.95$ corresponding to acceptable model performance and $\mathrm{B}_{\mathrm{f}}<0.87$ or $>1.43$ reflecting unacceptable model performance (Mejlholm et al., 2010). $A_{f}>1.5$ has been suggested to indicate an incomplete model or systematic deviation between observed and predicted $\mu_{\max }$-values (Mejlholm and Dalgaard, 2013). Firstly, we used this approached to evaluate the effect of interaction among environmental factors (eq. (4)). Secondly, the approach was applied to evaluate if the new model could appropriately predict the inhibitory effect of commercial melting salt preparations on the growth of L. monocytogenes. For these predictions the concentrations of individual phosphates in the commercial melting salt preparations were analysed and concentrations of P1, P2 and P3 were used as model input to obtain predictions 
267 (Table 5). Finally, the performance of the new model was evaluated by comparing predicted and 268 observed growth responses in 20 challenge tests with spreadable processed cheese (see section 2.5). 269 Predicted and observed growth and no-growth responses were assessed by calculating the 270 percentage of all samples that were correctly predicted with or without inclusion in eq. 4 of the term 271 for interaction between environmental factors $(\xi)$. Incorrect predictions were considered as fail-safe 272 (growth predicted with no growth observed) or fail-dangerous (no growth predicted with growth 273 observed). $\psi$-values (eq. (5)) was used to describe how far the predicted response (growth or no274 growth) was from the growth boundary $(\psi=1)$.

The acceptable simulation zone (ASZ) approach was used to compare observed and predicted growth in challenge tests were growth was observed under constant or dynamic 277 temperature storage. The acceptable interval was defined as +0.5 and $-1.0 \mathrm{Log} \mathrm{cfu} / \mathrm{g}$ from the 278 simulated growth of L. monocytogenes. When at least $70 \%$ of the observed values were within ASZ, 279 the simulation was considered acceptable (Oscar, 2007; Velugoti et al., 2011).

Three existing L. monocytogenes growth models were evaluated to assess their ability to 282 predict growth responses in spreadable processed cheese. The studied models were: (a) the model of 283 Mejlholm and Dalgaard (2009) previously evaluated for different non-fermented dairy products 284 (Mejlholm et al., 2010), (b) the model of Augustin et al. (2005) developed for cheese and including 285 terms for temperature, $\mathrm{pH}, \mathrm{NaCl} / \mathrm{a}_{\mathrm{w}}$, phenol, nitrite and $\mathrm{CO}_{2}$ and (c) the ComBase model including 286 the effect of temperature, $\mathrm{pH}, \mathrm{NaCl} / \mathrm{a}_{\mathrm{w}}$ and lactic acid (Combase, 2012). 
Model parameters and standard errors were estimated by using GraphPad PRISM (version 8, GraphPad Software, San Diego, CA, USA). F-tests to determine significant lag times were performed using Microsoft Excel 2010 (Microsoft Corp., Redmond, WA, USA).

\section{Results}

3.1. Development of a new L. monocytogenes growth and growth boundary model

The fitted MIC-values for phosphates were $14.9 \pm 1.1 \%, 9.4 \pm 0.4 \%, 7.6 \pm 0.2 \%$ in the water phase for orthophosphate (P1), di-phosphate (P2), tri-phosphate (P3), respectively (Fig. 1; Table 4). The fitted MIC-values for trisodium citrate (TC) salts and undissociated citric acid $\left(\mathrm{CAC}_{\mathrm{U}}\right)$ were

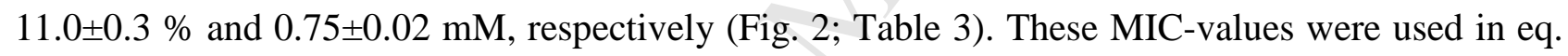
(4) together with a $\mu_{r e f}$-value of $0.4191 / \mathrm{h}$ as determined at $25^{\circ} \mathrm{C}$ by Mejlholm and Dalgaard (2009). When predictions by the new model (Eq. (4)) were performed either the MIC-value for TC or $\mathrm{CAC}_{\mathrm{U}}$ was used.

3.2. Challenge test with spreadable processed cheese

Commercial spreadable processed cheese showed little variation in initial $\mathrm{pH}(6.1-6.3), \mathrm{a}_{\mathrm{w}}$ (0.969-0.975) or concentrations of P1 (1.90-2.14\%) and TC (0.49-0.58\%) (Table 2). More variability was observed for water phase concentrations of lactic acid (4120-12,624 ppm), acetic acid (619-1,594 ppm) and citric acid (518-7,708 ppm) (Table 2).

L. monocytogenes grew in commercial spreadable processed cheese at $5,10,15$ and $22^{\circ} \mathrm{C}$ and $\mu_{\max }$-values were influenced by storage conditions and product characteristics (Table 2 and 3 ). 
As expected storage temperature had a pronounced effect on L. monocytogenes growth rate as seen for challenge tests 15,16 and 17 which were performed with batch 3 of a commercial spreadable processed cheese and therefore had the same product characteristics (Table 2; Table 3). Triphosphate (P3) concentration had a major effect on $L$. monocytogenes $\mu_{\text {max }}$-values, as suggested by their fitted MIC-values and confirmed by challenge tests 5 and 6 (Table 2, 3 and 4).

\subsection{Evaluation of the new L. monocytogenes growth and growth boundary model}

Broth studies with combinations of phosphates and citrate salt or undissociated citric acid suggested the need to include the growth inhibiting effect of interaction between these factors in the new growth and growth boundary model. By including $\varphi[\mathrm{P} 1] ; \varphi[\mathrm{P} 2] ; \varphi[\mathrm{P} 3] ;$ and either $\varphi[\mathrm{TC}]$ or $\varphi\left[\mathrm{CAC}_{\mathrm{U}}\right]$ in eq. (7) the $\mathrm{B}_{\mathrm{f}}$ and $\mathrm{A}_{\mathrm{f}}$ values changed from $1.55 / 1.67$ to $1.00 / 1.61$. The seven studied commercial melting salt preparations all reduced growth rates of L. monocytogenes at $25^{\circ} \mathrm{C}$ in $\mathrm{BHI}$ broth with pH 6.2 and this growth inhibiting effect was on average acceptably predicted by eq. 4 when using concentrations of P1, P2 and P3 as model input. On average for the $94 \mu_{\max }$-values determined in broth the $\mathrm{B}_{\mathrm{f}}$ and $\mathrm{A}_{\mathrm{f}}$ were 1.42 and 1.46, respectively (Table 5). Specifically, the model predicted growth with acceptable model performance for DP, PZ35, PZ189 and S9K but overestimates growth for BUDAL and to a lesser extend for PZ6 and S9 (Table 5).

For challenge test with spreadable processed cheese the new model predicted growth rates of L. monocytogenes at constant temperature with a good performance as determined from independent growth curves $(n=42)$ belonging to a total of 14 challenge test where growth was observed (Table 3). Comparison of observed and predicted $\mu_{\max }$-values, using either $M I C_{T C}(\%)$ or $M I C_{U C A C}(\mathrm{mM})$ (Fig. 2; Eq. (1); Eq. (3)), resulted in $\mathrm{B}_{\mathrm{f}} / \mathrm{A}_{\mathrm{f}}$-values of 1.06/1.35 or 1.12/1.29, respectively (Table 6). For commercial $(n=27)$ or customized $(n=15)$ spreadable processed cheese, 
$\mathrm{B}_{\mathrm{f}} / \mathrm{A}_{\mathrm{f}}$-values were $1.15 / 1.33$ and $0.91 / 1.39$, respectively, when using $M I C_{T C}(\%)$. When using $M I C_{U C A C}(\mathrm{mM})$ similar $\mathrm{B}_{\mathrm{f}} / \mathrm{A}_{\mathrm{f}}-$ values of $1.17 / 1.36$ and $1.05 / 1.29$ were obtained.

$R L T$-values for growth in spreadable processed cheese showed considerable variability and they were not dependent on storage temperature (Table 3). The minimum, average and maximum $R L T$-values were $0.0,1.2$ and 13.9.

For challenge tests, eq. (4) with interaction between environmental factors ( $\xi$ ) resulted in 89 $\%$ correct prediction of growth and no-growth responses with $11 \%$ being fail-safe (Table 3 ). Without interaction between environmental factors $(\xi) 74 \%$ of the growth and no-growth responses were correctly predicted with $26 \%$ being fail-safe. Clearly, inclusion of the interaction term $(\xi)$ in eq. (4) was important to accurately predict growth responses of L. monocytogenes. The two fail-safe predictions $(11 \%)$ had $\psi$-values of 0.3 and 0.4 and these were not close to the growth boundary with $(\psi=1)$. Three correctly predicted no-growth responses had $\psi$-values of 1.2, 1.5 and 2.4 (Table $3)$.

On average $58 \%$ of the predicted cell concentrations were within the ASZ for spreadable processed cheese when calculated for 15 challenges where growth was observed resulting in 45 growth curves at constant and dynamic temperatures (Table 7, Fig. 3). Predictions were obtained using the minimum observed $R L T$-value for $L$. monocytogenes, $N_{\max }$ of $7.9 \mathrm{log} \mathrm{cfu} / \mathrm{g}$ and the fitted $M I C_{U} C_{C A}-$ value of $0.75 \mathrm{mM}$ (Table 7, Fig. 3). Lag times had a major effect on the ASZ scores. As examples, challenge test 15 with a significant lag time (306 h, Table 3) resulting in a very low ASZ value (31\%), however, when no significant lag time was observed at the same storage temperature (challenge test 12) a ASZ value of $62 \%$ was found (Table 7). For challenge test 1 and 15 growth rates were accurately predicted by the model but the presence of lag times resulted in low ASZ scores (Fig.3. a, d). To overcome this limitation of the model, we evaluated the use of average and 
maximum RLT-values but results were inferior to those obtained by applying the minimum RLTvalues (Table 7).

\subsection{Evaluation of existing models}

As expected, for spreadable processed cheese with melting salts, unacceptable model performance with $\mathrm{B}_{\mathrm{f}}$-values well above 1.43 were observed for both the model of Mejlholm and Dalgaard (2009) and the ComBase model. Acceptable performance with $B_{f}$ and $A_{f}$ of $0.93 / 1.30$ were determined for the model of Augustin et al. (2005) developed for cheese (Table 6).

\section{Discussion}

A new mathematical model to predict growth and growth boundary of L. monocytogenes in spreadable processed cheese was developed by expanding an existing cardinal parameter model with terms to account for the effect of orthophosphate, di-phosphate, tri-phosphate and a new MICvalue for undissociated citric acid of $0.75 \mathrm{mM}$ (Eq.(4)). The new model predicted acceptably the growth at constant and dynamic storage temperatures as well as the growth boundary of $L$. monocytogenes in spreadable processed cheese (Table 6, Table 7, Fig. 3h). The low average ASZ score of $58 \%$ was due to significant lag times in some challenge tests and predictions being fail-safe (Fig. 3 a, d). Similar effects of lag times on ASZ scores were previously observed for both $L$. monocytogenes and Salmonella spp. (Hereu et al., 2014; Velugoti et al. 2011).

Based on the performed evaluation of the model, its range of applicability included orthophosphate $(0.14$ to $4.98 \%)$, di-phosphate $(<0.01$ to $5.09 \%)$, tri-phosphate $(<0.01$ to $5.17 \%)$, lactic acid (6,371 to $15,328 \mathrm{ppm})$, acetic acid (568 to 3,483 ppm), citric acid (518 to 38,282 ppm) in the product water phase, $\mathrm{pH}(6.1$ to 6.6$), \mathrm{a}_{\mathrm{w}}(0.952$ to 0.975$)$ and temperature $\left(3.8\right.$ to $\left.22.0^{\circ} \mathrm{C}\right)$. The 
inhibitory effect of several dairy specific ingredients is included in the new model (Eq. (4)) and this makes the model of practical importance for product development, reformulation or risk assessment of spreadable processed cheese. As an example, for a spreadable processed cheese with $\mathrm{pH} 6.3, \mathrm{a}_{\mathrm{w}}$ 0.972 and water phase organic acid concentrations of $0.8 \%$ (lactic acid), $0.1 \%$ (acetic acid), $0.3 \%$ (citric acid) and $2.0 \%$ (orthophosphate), the predicted time for L. monocytogenes to reach the critical concentration of $2 \log \mathrm{cfu} / \mathrm{g}$ is $4-8$ days if this product is contaminated with $1-10 \mathrm{cfu} / \mathrm{g}$ by consumer handling, e.g. when opening a package, and then stored at $8^{\circ} \mathrm{C}$. A longer open shelf-life or larger safety margin may be desirable and the new model predicts that by substituting the orthophosphate with $2.0 \%$ tri-phosphate the reformulated product requires $13-17$ days at $8^{\circ} \mathrm{C}$ to reach the same critical concentration for L. monocytogenes. It seems interesting to apply the new model in combination with available models to predict growth or toxin formation by $C$. botulinum in spreadable process cheese containing melting salts (Glass et al., 2017; Schaffner et al., 1998; ter Steeg and Cuppers, 1995b) to formulate recipes that will inhibit growth of the relevant pathogens. For these applications the new model has the advantages of including the inhibitory effect of ingredients specific to spreadable processed cheese and being validated for these products. When food products are reformulated, product characteristics must be selected at a sufficient distance from the growth boundary so that $L$. monocytogenes does not grow as a consequence of intrinsic variability of product characteristics, storage conditions or strain variability. In this respect, the new model (Eq. (4)) includes the parameter $\psi$ as a quantitative measurement for the distance between specific environmental conditions and the growth boundary of L. monocytogenes $(\psi=1)$. As an example, a $\psi$ value of 0.20 was determined by the model for spreadable processed cheese with the following characteristics: $\mathrm{pH}$ 6.6, $\mathrm{a}_{\mathrm{w}}$ 0.970, $1.0 \%$ (lactic acid), $0.1 \%$ (acetic acid), $0.2 \%$ (citric acid), $0.7 \% \mathrm{P} 1,0.5 \% \mathrm{P} 2,0.6 \% \mathrm{P} 3$ in the water phase of product and stored at $15^{\circ} \mathrm{C}$ (Table 2, CT 5). These product characteristics are placed on the growth side of the growth boundary $(\psi<1)$. The new 
401

402

403

404

405

406

407

408

409

410

411

412

413

414

415

416

model can be used to optimize product characteristics to prevent growth of L. monocytogenes. The formulation studied in CT 5 can be changed to prevent growth and to obtain a product with a desired $\psi$-value of e.g. 2. With $\mathrm{pH}$ reduced from 6.6 to 5.8, water phase concentrations of lactic acid increased from $1 \%$ to $2.2 \%$, acetic acid increased from $0.1 \%$ to $0.35 \%$ and $\mathrm{P} 1$ reduced from 0.7 to $0.3 \%$ and P3 increased from $0.6 \%$ to $1.5 \%$ the predicted $\psi$-value becomes 2.1 .

The model of Augustin et al. (2005) also provided acceptable prediction for growth rates of L. monocytogenes in spreadable processed cheese (Table 6) and included the effect of temperature, $\mathrm{pH}, \mathrm{NaCl} / \mathrm{a}_{\mathrm{w}}$, phenol, nitrite and $\mathrm{CO}_{2}$. Without terms for organic acids and melting salts the potential of the Augustin et al. (2005) model to contribute to development and reformulation of spreadable processed cheese, however, is limited and in this respect the new model developed in the present study is more performant.

The present study estimated a lower undissociated citric acid MIC-value $\left(M I C_{U} C A C\right)$ for $L$. monocytogenes dairy strains $(0.75 \mathrm{mM})$ than Mejlholm and Dalgaard (2009) observed for seafood isolates $(2.21 \mathrm{mM})$. Future studies should compare model performance when using either $M I C_{U}$

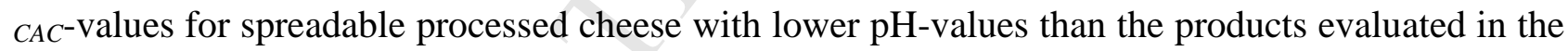
present study.

The approach used in the present study to develop an extensive model including the inhibiting effect of both organic acids and phosphate salts could also be interesting for C. botulinum as available predictive models with relevance for spreadable processed cheese include few environmental parameters (Glass et al., 2017; Schaffner et al., 1998; ter Steeg and Cuppers, 1995b).

\section{Conclusion}


The present study developed and validated a new model to predict growth and growth

424

425

boundary of L. monocytogenes in spreadable processed cheese. The obtained results demonstrate that interaction among environmental factors improved the performance of the model. This study confirmed that increasing concentrations of phosphate salts reduces the growth of L. monocytogenes and therefore, these salts can be used as growth inhibiting compounds. The model can be used to support spreadable processed cheese product development, reformulation or risk assessment. It seems interesting to include the new model in predictive microbiology application software such as the Food Spoilage and Safety Predictor (FSSP http://fssp.food.dtu.dk/) to facilitate prediction of the effect of product characteristics at constant and dynamic temperature storage conditions on growth of L. monocytogenes in spreadable processed cheese.

\section{Acknowledgements}

The Danish Dairy Research Foundation funded the present study as part of the project 'Predictive food microbiology tool for risk assessment and documentation of food safety'. 


\section{References}

Adams, M.R., Moss, M.O., McClure, P.J., 2016. Methods for the Microbiological Examination of Foods. In: Food Microbiology. The Royal Society of Chemistry, Croydon, UK, pp. 413-446.

Augustin, J.C., Zuliani, V., Cornu, M., Guillier, L., 2005. Growth rate and growth probability of Listeria monocytogenes in dairy, meat and seafood products in suboptimal conditions. Journal of Applied Microbiology 99, 1019-1042. https://doi.org/10.1111/j.1365-2672.2005.02710.x

ComBase, 2012. Web-based resource for quantitative and predictive food microbiology. https://www.combase.cc/index.php/en/ Accesed on 6 Febraury 2019

Coroller, L., Guerrot, V., Huchet, V., Le Marc, Y., Mafart, P., Sohier, D., Thuault, D., 2005. Modelling the influence of single acid and mixture on bacterial growth. International Journal of Food Microbiology 100, 167-178. https://doi.org/10.1016/j.ijfoodmicro.2004.10.014

Dalgaard, P., 2009. Modelling of microbial growth. Bulletin of the International Dairy Federation $433,45-60$.

Dalgaard, P., Jørgensen, L.V., 2000. Cooked and brined shrimps packed in a modified atmosphere have a shelf life of $>7$ months at $0^{\circ} \mathrm{C}$, but spoil in $4-6$ days at $25^{\circ} \mathrm{C}$. International Journal of Food Science and Technology, 35, 431-442. https://doi.org/10.1046/j.1365-2621.2000.00402.x

Dalgaard, P., Koutsoumanis, K., 2001. Comparison of maximum specific growth rates and lag times estimated from absorbance and viable count data by different mathematical models. Journal of Microbiological Methods 43, 183-196. https://doi.org/10.1016/S0167$\underline{\text { 7012(00)00219-0 }}$

De Jong, A.E.I., Verhoeff-Bakkenes, L., Nauta, M.J., De Jonge, R., 2008. Cross-contamination in the kitchen: Effect of hygiene measures. Journal of Applied Microbiology 105, 615-624. https://doi.org/10.1111/j.1365-2672.2008.03778.x

EC, 2005. Commission Regulation (EC) No. 2073/2005 of 15 November 2005 on microbiological criteria for foodstuffs. Official Journal of the European Communitites 338, 1-26.

EFSA, 2018.Listeria monocytogenes contamination of ready-to-eat foods and the risk for human health in the EU. EFSA Journal 16, 1-5134. https://efsa.onlinelibrary.wiley.com/doi/epdf/10.2903/j.efsa.2018.5134

Evans, E.W., Redmond, E.C., 2018. Behavioral observation and microbiological analysis of older adult consumers' cross-contamination practices in a model domestic kitchen. Journal of Food Protection 81, 569-581. https://doi.org/10.4315/0362-028X.JFP-17-378

Fox, P.F., Guinee, T.P., Cogan, T.M., McSweeney, P.L.H., 2017. Processed cheese and substitute/imitation cheese products, in: Fundamentals of Cheese Science. Springer Nature, New York, pp. 589-627.

Glass, K.A., Mu, M., LeVine, B., Rossi, F., 2017. Inhibition of Clostridium botulinum in model reduced-sodium pasteurized prepared cheese products. Journal of Food Protection 80, 14781488. https://doi.org/10.4315/0362-028X.JFP-17-027

Guinee, T.P., Products, D., Cork, C., 2004. Pasteurized processed cheese and substitute/imitation 
cheese products, in: Fox, P.F., McSweeney, P.L.H., Cogan, T.M., Guinee, T.P., (Eds.) Cheese: Chemistry, Physics and Microbiology. Elsevier Academic Press, London, pp. 349-394. https://doi.org/10.1016/S1874-558X(04)80052-6

Hereu, A., Dalgaard, P., Garriga, M., Aymerich, T., Bover-Cid, S., 2014. Analysis and modelling the growth behaviour of Listeria monocytogenes on RTE cooked meat products after a high pressure treatment at $400 \mathrm{MPa}$. International Journal of Food Microbiology, 186, 84-94. https: //doi: 10.1016/j.ijfoodmicro.2014.06.020

James, S.J., Evans, J., James, C., 2008. A review of the performance of domestic refrigerators. Journal of Food Engineering 87, 2-10. https://doi.org/10.1016/j.jfoodeng.2007.03.032

Kim, N.H., Lee, N.Y., Kim, M.G., Kim, H.W., Cho, T.J., Joo, I.S., Heo, E.J., Rhee, M.S., 2018. Microbiological criteria and ecology of commercially available processed cheeses according to the product specification and physicochemical characteristics. Food Research International 106, 468-474. https://doi.org/10.1016/j.foodres.2018.01.014

Le Marc, Y., Huchet, V., Bourgeois, C.M., Guyonnet, J.P., Mafart, P., Thuault, D., 2002. Modelling the growth kinetics of Listeria as a function of temperature, $\mathrm{pH}$ and organic acid concentration. International Journal of Food Microbiology 73, 219-237. https://doi.org/10.1016/S0168$\underline{1605(01) 00640-7}$

Loessner, M.J., Maier, S.K., Schiwek, P., Scherer, S., 1997. Long-chain polyphosphates inhibition growth of Clostridium tyrobutyricum in processed cheese spreads. Journal of Food Protection 60, 493-498. https://doi.org/10.4315/0362-028X-60.5.493

Maier, S.K., Scherer, S., Loessner, M.J., Maier, S.K., Scherer, S., 1999. Long-chain polyphosphate causes cell lysis and inhibits Bacillus cereus septum formation, which is dependent on divalent cations. Applied and Enviromental Microbiology 65, 3942-3949.

Martinez-Rios, V., Dalgaard, P., 2016. Modelling and predicting growth of psychrotolerant pseudomonads in milk and cottage cheese. International Journal of Food Microbiology 216, 110-120. https://doi.org/10.1016/j.ijfoodmicro.2015.09.020

Martinez-Rios, V., Gkogka, E., Dalgaard, P., 2019. New term to quantify the effect of temperature on $\mathrm{pH}_{\text {min}}$-values used in cardinal parameter growth models for Listeria monocytogenes. Frontiers in Microbiology 10, 1510. https://doi.org/10.3389/fmicb.2019.01510

Maurer, A., 2012. Processed cheese manufacture and stabilization of dairy products. A JOHA ${ }^{\circledR}$ guide. BK Giulini GmbH: Ludwigshafen.

Mejlholm, O., Dalgaard, P., 2009. Development and validation of an extensive growth and growth boundary model for Listeria monocytogenes in lightly preserved and ready-to-eat shrimp. Journal of Food Protection 72, 2132-2143. https://doi.org/10.4315/0362-028X-72.10.2132

Mejlholm, O., Gunvig, A., Borggaard, C., Blom-Hanssen, J., Mellefont, L., Ross, T., Leroi, F., Else, T., Visser, D., Dalgaard, P., 2010. Predicting growth rates and growth boundary of Listeria monocytogenes - An international validation study with focus on processed and readyto-eat meat and seafood. International Journal of Food Microbiology 141, 137-150. https://doi.org/10.1016/j.ijfoodmicro.2010.04.026 
Mejlholm, O., Dalgaard, P., 2013. Development and validation of an extensive growth and growth boundary model for psychrotolerant Lactobacillus spp. in seafood and meat products. International Journal of Food Microbiology 167, 244-260. https://doi.org/10.1016/j.ijfoodmicro.2013.09.013

Mellefont, L.A., Ross, T., 2003. The effect of abrupt shifts in temperature on the lag phose duration of Escherichia coli and Klebsiella oxytoca. International Journal of Food Microbiology 60, 295-305. https://doi.org/10.1016/S0168-1605(02)00378-1

Oscar, T.P., 2007. Predictive models for growth of Salmonella typhimurium DT104 from low and high initial density on ground chicken with a natural microflora. Food Microbiology 24, 640651. https://doi.org/10.1016/j.fm.2006.11.003

Redmond, E.C., Griffith, C.J., 2003. Consumer food handling in the home: a review of food safety studies. Journal of food protection 66, 130-61. https://doi.org/10.4315/0362-028X-66.1.130

Resnik, S.L., Chirife, J., 1988. Proposed theoretical water activity values at various tempertures for selected solutions to be used as reference sources in the range of microbial growth. Journal of Food Protection, 51, 419-423. https://doi.org/10.4315/0362-028X-51.5.419

Roccato, A., Uyttendaele, M., Membré, J.M., 2017. Analysis of domestic refrigerator temperatures and home storage time distributions for shelf-life studies and food safety risk assessment. Food Research International 96, 171-181. https://doi.org/10.1016/j.foodres.2017.02.017

Ross, T., 1996. Indices for performance evaluation of predictive models in food microbiology. Journal of Applied Bacteriology 81, 501-508. https://doi.org/10.1111/j.13652672.1996.tb03539.x

Ross, T., Dalgaard, P., 2004. Secondary models, in: Mckellar, R.C, Lu, X. (Ed.), Modeling Microbial Responses in Foods. CRC Press, Boca Raton, FL, USA., pp. 63-150.

Rosso, L., Bajard, S., Flandrois, J.P., Lahellec, C., Fournaud, J., Veit, P., 1996. Differential growth of Listeria monocytogenes at 4 and $8^{\circ} \mathrm{C}$ : Consequences for the shelf life of chilled products. Journal of Food Protection 59, 944-949. https://doi.org/10.4315/0362-028X-59.9.944

Schaffner, D.W., Ross, W.H., Montville, T.J., 1998. Analysis of the influence of enviromental parameters Clostridium botulinum time-to-toxicity by using three modeling approaches. Applied and Enviromental Microbiology, 64, 4416-4422.

ter Steeg, P.F., Cuppers, H.G.A.M., Hellemons, J.C., Rijke, G., 1995a. Growth of proteolytic Clostridium botulinum in process cheese products: I. Data acquisition for modeling the influence of $\mathrm{pH}$, sodium chloride, emulsifying salts, fat, dry basis, and temperature. Journal of Food Protection 58, 1091-1099. https://doi.org/10.4315/0362-028X-58.10.1091

ter Steeg, P.F., Cuppers, H.G.A.M., 1995b. Growth of proteolytic Clostridium botulinum in process cheese products: II. Predictive modelling. Journal of Food Protection, 58, 1100-1108. https://doi.org/10.4315/0362-028X-58.10.1100

Tanaka, N., Trausman, E., Plantinga, P., Finn, L., Flom, W., Meske, L., Guggisberg, J., 1986. Evaluation of factors involved in antibotulinal properties of pasteurized process cheese spreads. Journal of Food Protection, 49, 526-531. https://doi.org/10.4315/0362-028X-49.7.526 
564 Tompkin, R.B., 1983. Indirect antimicrobial effects in foods: phosphates. Journal of Food Safety 6, $565 \quad 13-27$.

566 Velugoti, P.R., Bohra, L.K., Juneja, V.K., Huang, L., Wesseling, A.L., Subbiah, J., Thippareddi, H., 567 2011. Dynamic model for predicting growth of Salmonella spp. in ground sterile pork. Food 568 Microbiology 28, 796-803. https://doi.org/10.1016/j.fm.2010.05.007

569 WHO, 2006. Five keys to safer food manual.

570 https://www.who.int/foodsafety/publications/5keysmanual/en/ (accessed 30 January 2019) 
Table 1. Product information for phosphate, citrate and commercial melting salts.

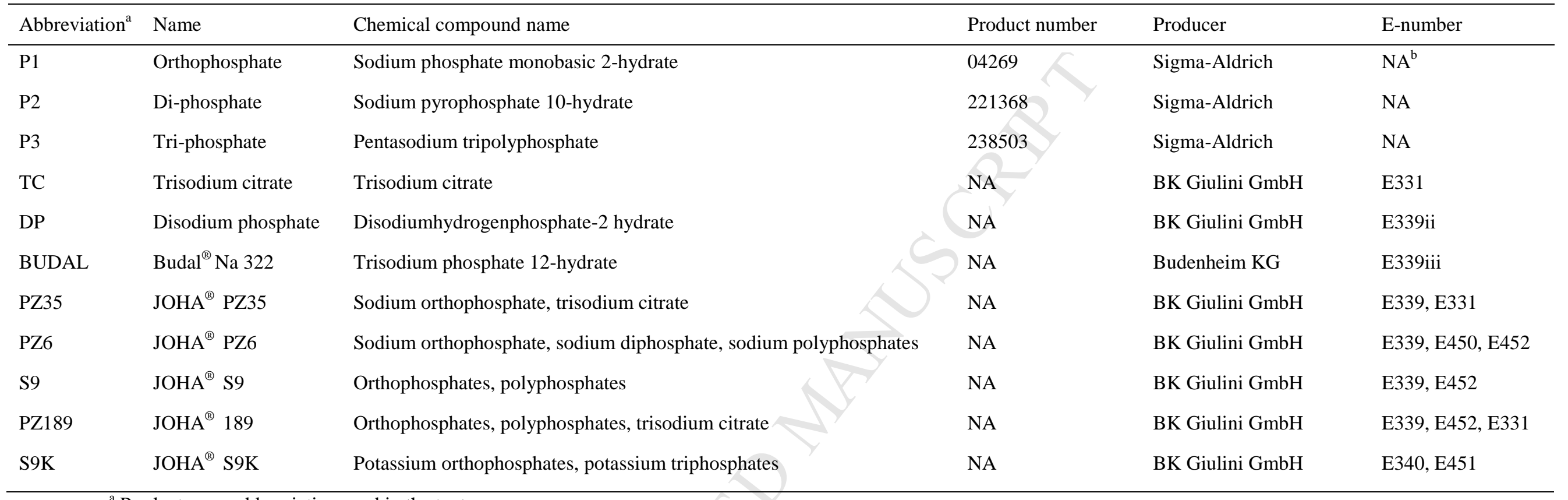

${ }^{a}$ Product name abbreviation used in the text

${ }^{\mathrm{b}} \mathrm{NA}$ : information not available 
Table 2. Storage conditions and product characteristics for challenge tests with processed spreadable cheese.

Product characteristics (Avg. \pm SD)

\begin{tabular}{|c|c|c|c|c|c|c|c|c|c|c|c|c|c|}
\hline \multirow{3}{*}{$\mathrm{CT}^{\mathrm{b}}$} & \multirow{3}{*}{ Batch } & \multirow{3}{*}{$\begin{array}{l}\text { Type of } \\
\text { cheese }\end{array}$} & \multirow{3}{*}{$\mathrm{n}^{\mathrm{c}}$} & \multirow{3}{*}{$\begin{array}{c}\text { Storage } \\
\text { temp. } \\
\left({ }^{\circ} \mathrm{C}\right)\end{array}$} & \multirow{2}{*}{\multicolumn{5}{|c|}{ Organic acids in water phase (ppm) }} & 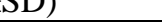 & 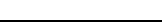 & $\tau_{2}$ & \\
\hline & & & & & & & & & & \multicolumn{4}{|c|}{ Melting salts in water phase $(\%)$} \\
\hline & & & & & $\mathrm{pH}$ & $a_{w}$ & Lactic acid & Acetic acid & Citric acid & $\mathrm{P} 1^{\mathrm{d}}$ & $\mathrm{P} 2^{\mathrm{e}}$ & $P 3^{\mathrm{f}}$ & $\mathrm{TC}^{\mathrm{g}}$ \\
\hline 1 & 1 & Customized & 3 & $14.9 \pm 0.2$ & $6.1 \pm 0.1$ & $0.972 \pm 0.000$ & $9,970 \pm 2,013$ & $1,158 \pm 53$ & $1,337 \pm 293$ & $2.61 \pm \mathrm{NA}^{\mathrm{h}}$ & $<0.01$ & $<0.01$ & $0.23 \pm \mathrm{NA}$ \\
\hline 2 & 2 & Customized & 3 & $14.9 \pm 0.2$ & $6.2 \pm 0.3$ & $0.970 \pm 0.004$ & $11,605 \pm 588$ & $1,272 \pm 57$ & $1,493 \pm 91$ & $4.98 \pm \mathrm{NA}$ & $<0.01$ & $<0.01$ & $0.25 \pm \mathrm{NA}$ \\
\hline 3 & 3 & Customized & 3 & $15.0 \pm 0.3$ & $6.4 \pm 0.2$ & $0.967 \pm 0.001$ & $11,969 \pm 1,611$ & $3,483 \pm 934$ & $1,709 \pm 384$ & $0.52 \pm \mathrm{NA}$ & $1.62 \pm \mathrm{NA}$ & $<0.01$ & $0.25 \pm \mathrm{NA}$ \\
\hline 4 & 4 & Customized & 3 & $15.0 \pm 0.3$ & $6.2 \pm 0.1$ & $0.971 \pm 0.001$ & $14,768 \pm 523$ & $3,231 \pm 922$ & $2,134 \pm 125$ & $0.48 \pm \mathrm{NA}$ & $5.09 \pm \mathrm{NA}$ & $<0.01$ & $0.26 \pm \mathrm{NA}$ \\
\hline 5 & 5 & Customized & 3 & $15.0 \pm 0.3$ & $6.6 \pm 0.1$ & $0.970 \pm 0.002$ & $9,559 \pm 1,630$ & $1,451 \pm 1,135$ & $1,642 \pm 281$ & $0.68 \pm \mathrm{NA}$ & $0.49 \pm \mathrm{NA}$ & $0.63 \pm \mathrm{NA}$ & $0.23 \pm \mathrm{NA}$ \\
\hline 6 & 6 & Customized & 3 & $15.0 \pm 0.3$ & $6.1 \pm 0.1$ & $0.967 \pm 0.000$ & $11,859 \pm 598$ & $1,701 \pm 13$ & $2,368 \pm 212$ & $0.74 \pm \mathrm{NA}$ & $1.45 \pm \mathrm{NA}$ & $5.17 \pm \mathrm{NA}$ & $0.28 \pm \mathrm{NA}$ \\
\hline 7 & 7 & Customized & 3 & $14.9 \pm 0.2$ & $6.4 \pm 0.1$ & $0.970 \pm 0.000$ & $7,051 \pm 1,030$ & $1,116 \pm 18$ & $11,510 \pm 290$ & $0.42 \pm \mathrm{NA}$ & $<0.01$ & $<0.01$ & $2.78 \pm \mathrm{NA}$ \\
\hline 8 & 8 & Customized & 3 & $14.9 \pm 0.2$ & $6.3 \pm 0.1$ & $0.963 \pm 0.001$ & $12,339 \pm 1,620$ & $2,162 \pm 1,116$ & $38,282 \pm 5,319$ & $0.44 \pm \mathrm{NA}$ & $<0.01$ & $<0.01$ & $5.01 \pm \mathrm{NA}$ \\
\hline 9 & 9 & Customized & 3 & $15.0 \pm 0.3$ & $6.4 \pm 0.2$ & $0.964 \pm 0.001$ & $9,514 \pm 2,760$ & $1,116 \pm 90$ & $1,289 \pm 479$ & $2.04 \pm \mathrm{NA}$ & $0.34 \pm \mathrm{NA}$ & $0.29 \pm \mathrm{NA}$ & $0.27 \pm \mathrm{NA}$ \\
\hline 10 & 10 & Customized & 3 & $15.0 \pm 0.3$ & $6.3 \pm 0.1$ & $0.952 \pm 0.001$ & $15,328 \pm 1,768$ & $1,630 \pm 227$ & $2,490 \pm 1,390$ & $3.90 \pm \mathrm{NA}$ & $0.54 \pm \mathrm{NA}$ & $3.67 \pm \mathrm{NA}$ & $0.28 \pm \mathrm{NA}$ \\
\hline 11 & 1 & Commercial & 3 & $22.0 \pm 0.2$ & $6.2 \pm 0.0$ & $0.969 \pm 0.001$ & $6,371 \pm 22$ & $958 \pm 4$ & $518 \pm 12$ & $1.90 \pm \mathrm{NA}$ & $<0.01$ & $<0.01$ & $0.49 \pm \mathrm{NA}$ \\
\hline 12 & 2 & Commercial & 3 & $4.8 \pm 0.4$ & $6.2 \pm 0.0$ & $0.969 \pm 0.001$ & $7,641 \pm 865$ & $568 \pm 178$ & $2,558 \pm 290$ & $1.94 \pm \mathrm{NA}$ & $<0.01$ & $<0.01$ & $0.50 \pm \mathrm{NA}$ \\
\hline 13 & 2 & Commercial & 3 & $10.1 \pm 0.2$ & $6.2 \pm 0.0$ & $0.969 \pm 0.001$ & $7,641 \pm 865$ & $568 \pm 178$ & $2,558 \pm 290$ & $1.94 \pm \mathrm{NA}$ & $<0.01$ & $<0.01$ & $0.50 \pm \mathrm{NA}$ \\
\hline 14 & 2 & Commercial & 3 & $14.5 \pm 0.2$ & $6.2 \pm 0.0$ & $0.969 \pm 0.001$ & $7,641 \pm 865$ & $568 \pm 178$ & $2,558 \pm 290$ & $1.94 \pm \mathrm{NA}$ & $<0.01$ & $<0.01$ & $0.50 \pm \mathrm{NA}$ \\
\hline 15 & 3 & Commercial & 3 & $4.8 \pm 0.4$ & $6.2 \pm 0.0$ & $0.972 \pm 0.001$ & $13,105 \pm 4,612$ & $1,559 \pm 345$ & $5,392 \pm 1,826$ & $1.91 \pm \mathrm{NA}$ & $<0.01$ & $<0.01$ & $0.49 \pm \mathrm{NA}$ \\
\hline 16 & 3 & Commercial & 3 & $10.1 \pm 0.2$ & $6.2 \pm 0.0$ & $0.972 \pm 0.001$ & $13,105 \pm 4,612$ & $1,559 \pm 345$ & $5,392 \pm 1,826$ & $1.91 \pm \mathrm{NA}$ & $<0.01$ & $<0.01$ & $0.49 \pm \mathrm{NA}$ \\
\hline 17 & 3 & Commercial & 3 & $14.5 \pm 0.2$ & $6.2 \pm 0.0$ & $0.972 \pm 0.001$ & $13,105 \pm 4,612$ & $1,559 \pm 345$ & $5,392 \pm 1,826$ & $1.91 \pm \mathrm{NA}$ & $<0.01$ & $<0.01$ & $0.49 \pm \mathrm{NA}$ \\
\hline 18 & 4 & Commercial & 3 & $7.2 \pm 0.2$ & $6.1 \pm 0.0$ & $0.969 \pm 0.001$ & $12,624 \pm 1,468$ & $1,436 \pm 159$ & $7,612 \pm 1,062$ & $2.14 \pm \mathrm{NA}$ & $<0.01$ & $<0.01$ & $0.57 \pm \mathrm{NA}$ \\
\hline 19 & 4 & Commercial & 3 & $11.1 \pm 0.2$ & $6.1 \pm 0.0$ & $0.969 \pm 0.001$ & $12,633 \pm 763$ & $1,594 \pm 140$ & $7,708 \pm 402$ & $2.13 \pm \mathrm{NA}$ & $<0.01$ & $<0.01$ & $0.58 \pm \mathrm{NA}$ \\
\hline 20 & 4 & Commercial & 3 & $3.8-19.4^{\mathrm{i}}$ & $6.3 \pm 0.0$ & $0.975 \pm 0.000$ & $8,368 \pm 717$ & $1,042 \pm 226$ & $5,416 \pm 284$ & $1.92 \pm \mathrm{NA}$ & $<0.01$ & $<0.01$ & $0.53 \pm \mathrm{NA}$ \\
\hline
\end{tabular}

${ }^{a}$ Avg.: average; SD: standard deviation $(\mathrm{n}=3)$

${ }^{\mathrm{b}}$ Challenge test

${ }^{c}$ Number of growth curves per challenge test

${ }^{\mathrm{d}}$ P1: orthophosphate

e 2 : di-phosphate

${ }^{\mathrm{f}} \mathrm{P}$ 3: tri-phosphate

g TC: trisodium citrate

${ }^{\mathrm{h}} \mathrm{NA}$, not available as pooled sample was analysed by Eurofins.

${ }^{\mathrm{i}}$ Dynamic storage temperature. 
Table 3. Growth parameters of L. monocytogenes in challenge tests with processed spreadable cheese.

\begin{tabular}{|c|c|c|c|c|c|c|c|c|c|}
\hline \multirow[b]{2}{*}{$\mathrm{CT}^{\mathrm{b}}$} & \multirow[b]{2}{*}{$\begin{array}{l}\text { Type of } \\
\text { cheese }\end{array}$} & \multicolumn{5}{|c|}{ Growth parameter values (Avg. \pm SD) ${ }^{\mathrm{a}}$} & \multirow[b]{2}{*}{$\begin{array}{l}\text { Duration of } \\
\text { exp. (days) }\end{array}$} & \multirow[b]{2}{*}{$\psi^{\mathrm{c}}$} & \multirow[b]{2}{*}{$\begin{array}{l}\text { Predicted growth/no-growth } \\
\text { responses }\end{array}$} \\
\hline & & $\begin{array}{l}\text { Lag-time } \\
\text { (h) }\end{array}$ & $R L T(\mathrm{~h})$ & $\begin{array}{l}\log N_{0} \\
(\mathrm{cfu} / \mathrm{g})\end{array}$ & $\begin{array}{c}\log N_{\max } \\
(\mathrm{cfu} / \mathrm{g})\end{array}$ & $\mu_{\max }(1 / \mathrm{h})$ & & & \\
\hline 1 & Customized & $222 \pm 11$ & $13.9 \pm 2.1$ & $2.3 \pm 0.2$ & $4.9 \pm 0.1$ & $0.043 \pm 0.01$ & 19.1 & 0.3 & Correct \\
\hline 2 & Customized & $114 \pm 18$ & $7.2 \pm 1.8$ & $2.5 \pm 0.1$ & $7.0 \pm 0.6$ & $0.043 \pm 0.00$ & 20.1 & 0.3 & Correct \\
\hline 3 & Customized & $0.0 \pm 0.0^{\mathrm{d}}$ & $0.0 \pm 0.0$ & $2.4 \pm 0.1$ & $2.2 \pm 0.1$ & $0.000 \pm 0.00^{\mathrm{e}}$ & 51.0 & 0.4 & Fail-safe \\
\hline 4 & Customized & $0.0 \pm 0.0^{\mathrm{d}}$ & $0.0 \pm 0.0$ & $2.4 \pm 0.1$ & $2.1 \pm 0.1$ & $0.000 \pm 0.00^{\mathrm{e}}$ & 65.1 & 1.5 & Correct \\
\hline 5 & Customized & $0.0 \pm 0.0^{\mathrm{d}}$ & $0.0 \pm 0.0$ & $2.0 \pm 0.1$ & $6.1 \pm 0.2$ & $0.034 \pm 0.00$ & 17.9 & 0.2 & Correct \\
\hline 6 & Customized & $0.0 \pm 0.0^{\mathrm{d}}$ & $0.0 \pm 0.0$ & $2.4 \pm 0.1$ & $1.3 \pm 0.3$ & $0.000 \pm 0.00^{\mathrm{e}}$ & 65.0 & 2.4 & Correct \\
\hline 7 & Customized & $0.0 \pm 0.0^{\mathrm{d}}$ & $0.0 \pm 0.0$ & $2.4 \pm 0.2$ & $7.7 \pm 0.2$ & $0.102 \pm 0.00$ & 8.0 & 0.1 & Correct \\
\hline 8 & Customized & $0.0 \pm 0.0^{\mathrm{d}}$ & $0.0 \pm 0.0$ & $2.6 \pm 0.1$ & $7.8 \pm 0.1$ & $0.037 \pm 0.00$ & 20.0 & 0.3 & Correct \\
\hline 9 & Customized & $0.0 \pm 0.0^{\mathrm{d}}$ & $0.0 \pm 0.0$ & $2.2 \pm 0.2$ & $2.4 \pm 0.2$ & $0.000 \pm 0.00^{\mathrm{e}}$ & 51.0 & 0.3 & Fail-safe \\
\hline 10 & Customized & $0.0 \pm 0.0^{\mathrm{d}}$ & $0.0 \pm 0.0$ & $2.4 \pm 0.2$ & $1.7 \pm 0.4$ & $0.000 \pm 0.00^{\mathrm{e}}$ & 65.0 & 1.2 & Correct \\
\hline 11 & Commercial & $0.0 \pm 0.0^{\mathrm{d}}$ & $0.0 \pm 0.0$ & $2.0 \pm 0.1$ & $7.8 \pm 0.0$ & $0.106 \pm 0.00$ & 17.9 & 0.2 & Correct \\
\hline 12 & Commercial & $0.0 \pm 0.0^{\mathrm{d}}$ & $0.0 \pm 0.0$ & $1.4 \pm 0.1$ & $3.4 \pm 0.3$ & $0.006 \pm 0.00$ & 32.0 & 0.3 & Correct \\
\hline 13 & Commercial & $0.0 \pm 0.0^{\mathrm{d}}$ & $0.0 \pm 0.0$ & $1.3 \pm 0.2$ & $7.2 \pm 0.2$ & $0.016 \pm 0.00$ & 45.1 & 0.2 & Correct \\
\hline 14 & Commercial & $0.0 \pm 0.0^{\mathrm{d}}$ & $0.0 \pm 0.0$ & $1.3 \pm 0.0$ & $7.0 \pm 0.1$ & $0.051 \pm 0.00$ & 16.2 & 0.2 & Correct \\
\hline 15 & Commercial & $306 \pm 22$ & $3.9 \pm 0.4$ & $2.6 \pm 0.1$ & $7.2 \pm 0.2$ & $0.009 \pm 0.00$ & 83.0 & 0.5 & Correct \\
\hline 16 & Commercial & $43 \pm 16$ & $1.6 \pm 0.6$ & $2.9 \pm 0.0$ & $7.8 \pm 0.1$ & $0.027 \pm 0.00$ & 29.8 & 0.4 & Correct \\
\hline 17 & Commercial & $7 \pm 10^{f}$ & $0.6 \pm 0.9$ & $2.7 \pm 0.1$ & $7.9 \pm 0.2$ & $0.056 \pm 0.00$ & 17.0 & 0.3 & Correct \\
\hline 18 & Commercial & $157 \pm 56$ & $4.3 \pm 1.9$ & $1.0 \pm 0.0$ & $4.5 \pm 0.1$ & $0.015 \pm 0.00$ & 24.0 & 0.5 & Correct \\
\hline 19 & Commercial & $0.0 \pm 0.0^{\mathrm{d}}$ & $0.0 \pm 0.0$ & $1.2 \pm 0.3$ & $7.6 \pm 0.0$ & $0.035 \pm 0.00$ & 24.0 & 0.4 & Correct \\
\hline 20 & Commercial & - & - & $1.9 \pm 0.2$ & $7.6 \pm 0.3$ & - & 24.0 & - & \\
\hline
\end{tabular}

${ }^{\mathrm{a}}$ Avg: average; SD: standard deviation

${ }^{b}$ Challenge test.

${ }^{c} \psi$-value indicate how far the properties of a specific food product is from the predicted growth boundary of L. monocytogenes with $\psi=1.0$.

d No significant lag-time

No growth observed for duration of experiment.

${ }^{\mathrm{f}}$ One growth curve had a significant lag time out of three growth curves. 
Table 4. Cardinal parameter values for the effect of melting salts on L. monocytogenes growth.

\begin{tabular}{llll}
\hline & $\begin{array}{l}\text { Parameter values } \\
(\text { value } \pm \mathrm{SE})^{\mathrm{a}}\end{array}$ & $\mathrm{n} 1$ & $\mathrm{n} 2$ \\
\hline MIC $_{\mathrm{P} 1}(\%)$ & $14.9 \pm 1.1$ & 1 & 1 \\
$\mathrm{MIC}_{\mathrm{P} 2}(\%)$ & $9.4 \pm 0.4$ & 1 & 2 \\
$\mathrm{MIC}_{\mathrm{P} 3}(\%)$ & $7.6 \pm 0.2$ & 1 & 2 \\
$\mathrm{MIC}_{\mathrm{TC}}(\%)$ or $\mathrm{MIC}_{\mathrm{CAC}_{\mathrm{I}}}(\mathrm{mM})$ & $11.0 \pm 0.3$ or $0.75 \pm 0.02$ & 1 & 1 \\
\hline
\end{tabular}

$\mathrm{MIC}_{\mathrm{TC}}(\%)$ or $\mathrm{MIC}_{\mathrm{CAC}_{\mathrm{H}}}(\mathrm{mM})$

$11.0 \pm 0.3$ or $0.75 \pm 0.02$ 
Table 5. Observed and predicted effect of commercial melting salt preparations for growth of L. monocytogenes.

\begin{tabular}{|c|c|c|c|c|c|c|c|c|}
\hline \multirow[b]{2}{*}{$\begin{array}{l}\text { Commercial } \\
\text { melting salts }\end{array}$} & \multirow[b]{2}{*}{$\begin{array}{l}\text { Conc. studied } \\
(\mathrm{g} / \mathrm{ml})\end{array}$} & \multicolumn{4}{|c|}{ Percentage composition } & \multirow[b]{2}{*}{$\mathrm{n}^{\mathrm{a}}$} & \multirow[b]{2}{*}{$\mathrm{B}_{\mathrm{f}}^{\mathrm{b}}$} & \multirow[b]{2}{*}{$\mathrm{A}_{\mathrm{f}}^{\mathrm{c}}$} \\
\hline & & $\mathrm{P} 1$ & $\mathrm{P} 2$ & P3 & $\mathrm{TC}$ & & & \\
\hline $\mathrm{DP}$ & $0.0-9.1$ & 55 & 0 & 0 & 0 & 12 & 1.32 & 1.47 \\
\hline BUDAL & $0.0-15.7$ & 26 & 0 & 0 & 0 & 8 & 2.09 & 2.26 \\
\hline PZ35 & $0.0-8.2$ & 15 & 0 & 51 & 0 & 18 & 1.24 & 1.24 \\
\hline PZ6 & $0.0-3.9$ & 3 & 15 & 6 & 11 & 24 & 1.52 & 1.53 \\
\hline S9 & $0.0-3.4$ & 4 & 5 & 15 & 0 & 14 & 1.53 & 1.53 \\
\hline PZ189 & $0.0-4.5$ & 25 & 0 & 0 & 32 & 8 & 1.34 & 1.35 \\
\hline S9K & $0.0-3.5$ & 26 & 2 & 28 & 0 & 10 & 1.16 & 1.18 \\
\hline All data & & & & & & 94 & 1.42 & 1.46 \\
\hline
\end{tabular}

${ }^{\mathrm{a}} \mathrm{n}$, number of experiments

${ }^{\mathrm{b}} \mathrm{B}_{\mathrm{f}}$, bias factor

${ }^{\mathrm{c}} \mathrm{A}_{\mathrm{f}}$, accuracy factor 
Table 6. Comparison of observed and predicted growth of L. monocytogenes in spreadable processed cheese by bias and accuracy factors.

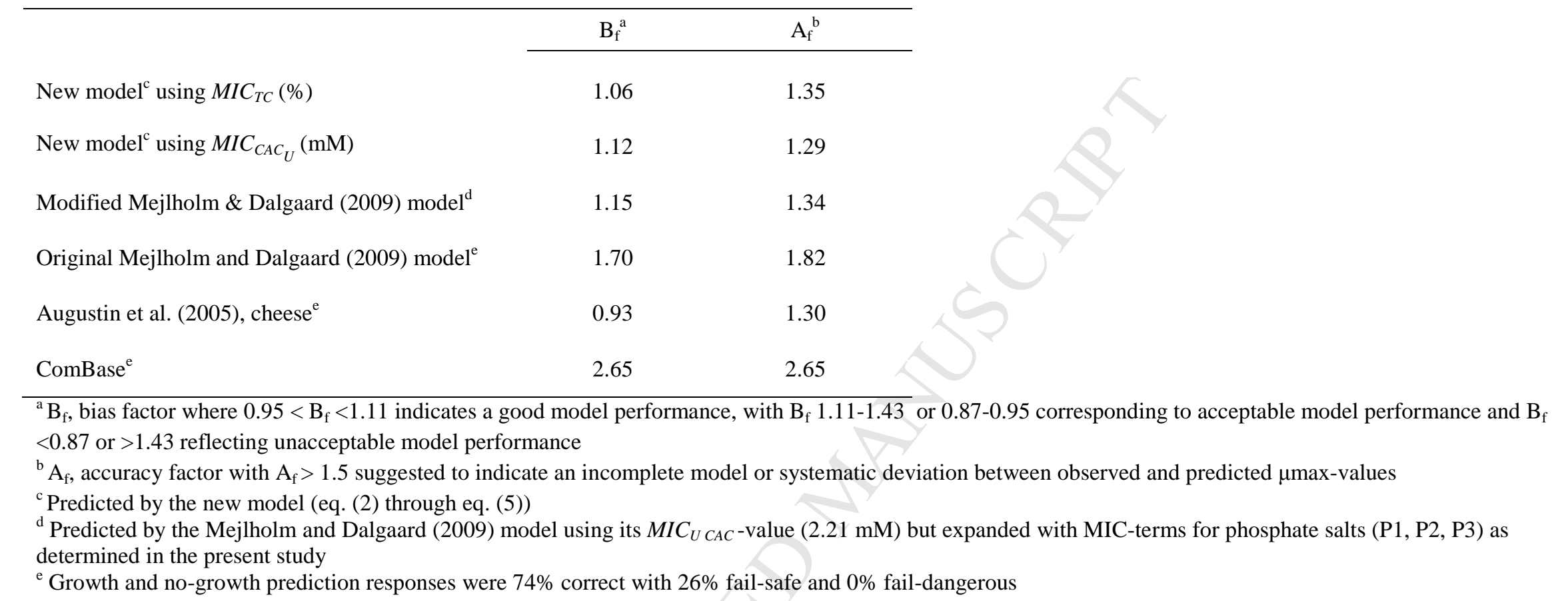


Table 7. Comparison of predicted and observed growth data using the acceptable simulation zone (ASZ) method.

\begin{tabular}{lll}
\hline $\mathrm{CT}^{\mathrm{a}}$ & Storage temperature $\left({ }^{\circ} \mathrm{C}\right)$ and growth data & $\begin{array}{l}\text { \% observations within ASZ } \\
\text { Predictions performed with new model } \\
\text { including } M I C_{U} \text { CAC }(\mathrm{mM})\end{array}$ \\
\hline $1^{\mathrm{c}}$ & $14.9 \pm 0.2$, Fig 3a & $17(22 / 56)$ \\
$2^{\mathrm{c}}$ & $14.9 \pm 0.2$ & $32(45 / 41)$ \\
$5^{\mathrm{c}}$ & $15.0 \pm 0.3$ & $41(46 / 26)$ \\
$7^{\mathrm{c}}$ & $14.9 \pm 0.2$ & $67(48 / 15)$ \\
$8^{\mathrm{c}}$ & $14.9 \pm 0.2$, Fig.3b & $95(79 / 13)$ \\
$11^{\mathrm{b}}$ & $22.0 \pm 0.2$, Fig. 3c & $97(93 / 43)$ \\
$12^{\mathrm{b}}$ & $4.8 \pm 0.4$ & $62(64 / 44)$ \\
$13^{\mathrm{b}}$ & $10.1 \pm 0.2$ & $32(32 / 49)$ \\
$14^{\mathrm{b}}$ & $14.5 \pm 0.2$ & $40(30 / 30)$ \\
$15^{\mathrm{b}}$ & $4.8 \pm 0.4$, Fig. 3d & $31(70 / 33)$ \\
$16^{\mathrm{b}}$ & $10.1 \pm 0.2$, Fig. 3e & $98(100 / 21)$ \\
$17^{\mathrm{b}}$ & $14.5 \pm 0.2$, Fig. 3f & $100(70 / 18)$ \\
$18^{\mathrm{b}}$ & $7.2 \pm 0.2$, Fig. 3g & $88(88 / 54)$ \\
$19^{\mathrm{b}}$ & $11.1 \pm 0.2$ & $67(45 / 27)$ \\
$20^{\mathrm{b}}$ & Dynamic (3.8-19.4 $\left.{ }^{\circ} \mathrm{C}\right)$, Fig. 3h & $91(21 / 18)$ \\
\hline \hline & Average ASZ score & $58(57 / 33)$ \\
\hline All data & & $63(61 / 34)$ \\
Commercial & & $49(49 / 31)$ \\
Customized $^{\mathrm{a}} \mathrm{C}$
\end{tabular}

${ }^{\mathrm{a}}$ Challenge test

${ }^{\mathrm{b}}$ Customized spreadable processed cheese

${ }^{c}$ Commercial spreadable processed cheese

${ }^{\mathrm{d}}$ Calculation of ASZ score with minimum RLT-value (average/maximum RLT-value). 

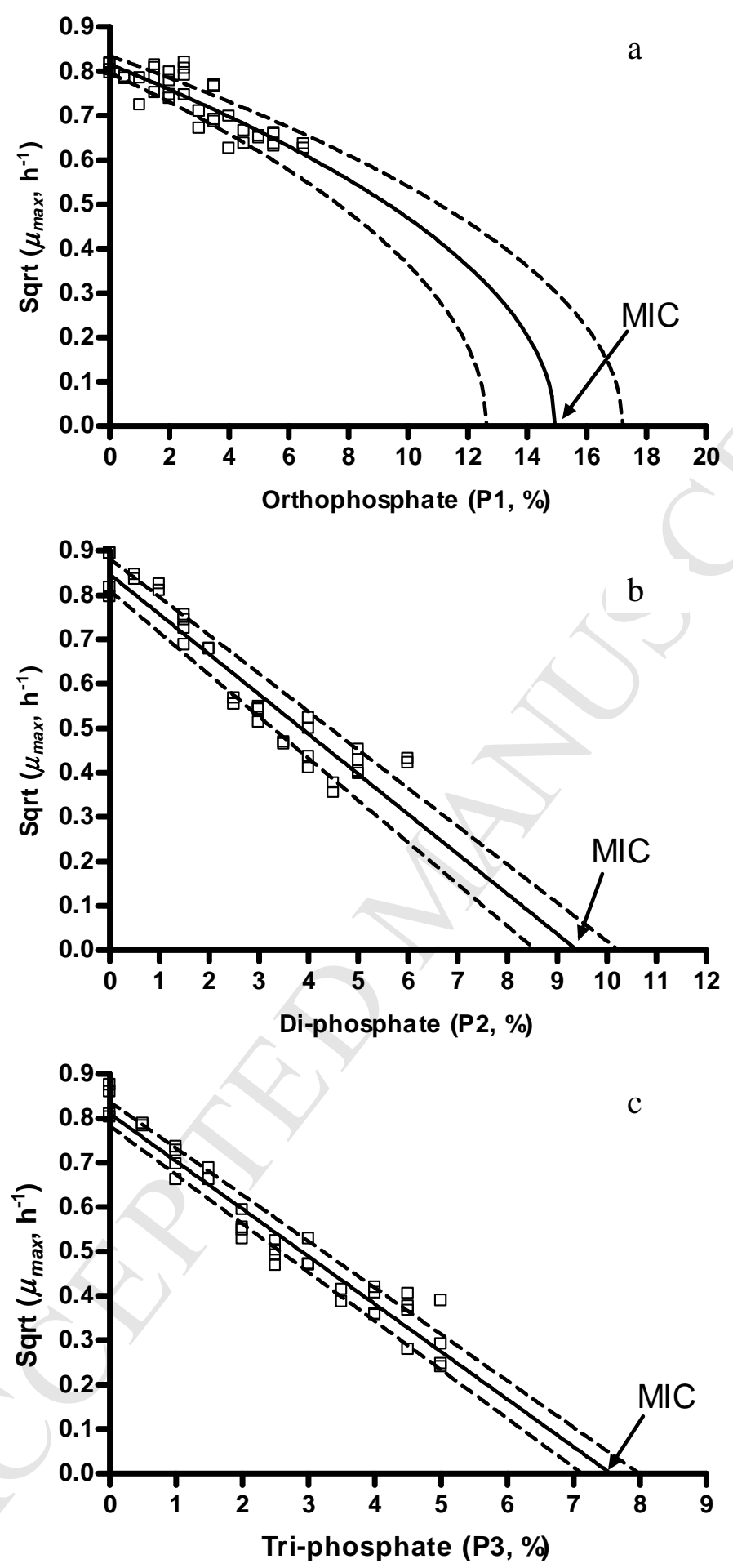

Fig.1. Maximum specific growth rates $\left(\mu_{\max }, 1 / \mathrm{h}\right)$ of $L$. monocytogenes in BHI broth at $25^{\circ} \mathrm{C}$ and $\mathrm{pH} 6.2$ as influenced by increasing concentrations of orthophosphate (a; P1), di-phosphate (b; P2) and tri-phosphate (c; P3). MIC-values for phosphate salts were determined by fitting eq. (3) to observed data ( $\square$ ). Solid and dashed lines represent the fitted (eq.( $3)$ ) and confidence intervals $(95 \%)$, respectively. 

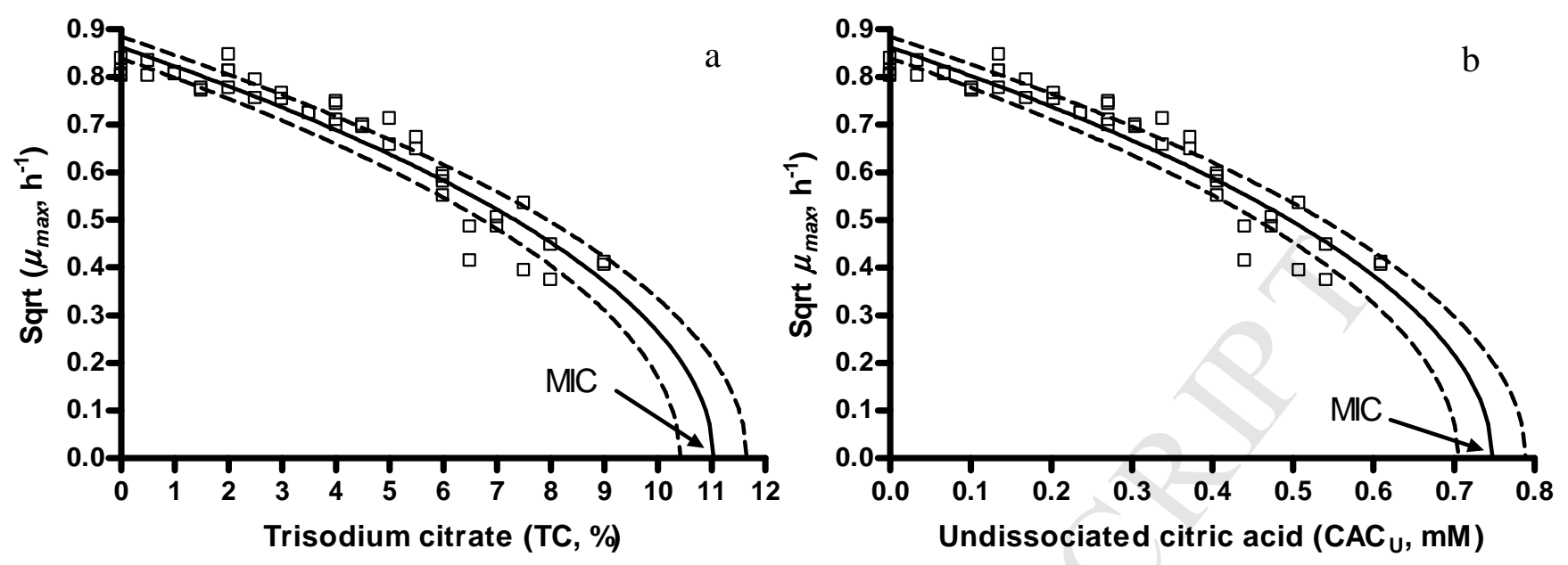

Fig.2. Effect of trisodium citrate (TC) (a) or undissociated citric acid (b) on maximum specific growth rates $\left(\mu_{\max }, 1 / \mathrm{h}\right)$ of L. monocytogenes in BHI broth at $25^{\circ} \mathrm{C}$ and $\mathrm{pH}$ 6.2. MIC-values of citrate salts and undissociated citric acid were determined by fitting eq. (3) to observed data ( $\square$ ). Solid and dashed lines represent the fitted (eq. (3)) and confidence intervals $(95 \%)$, respectively. 

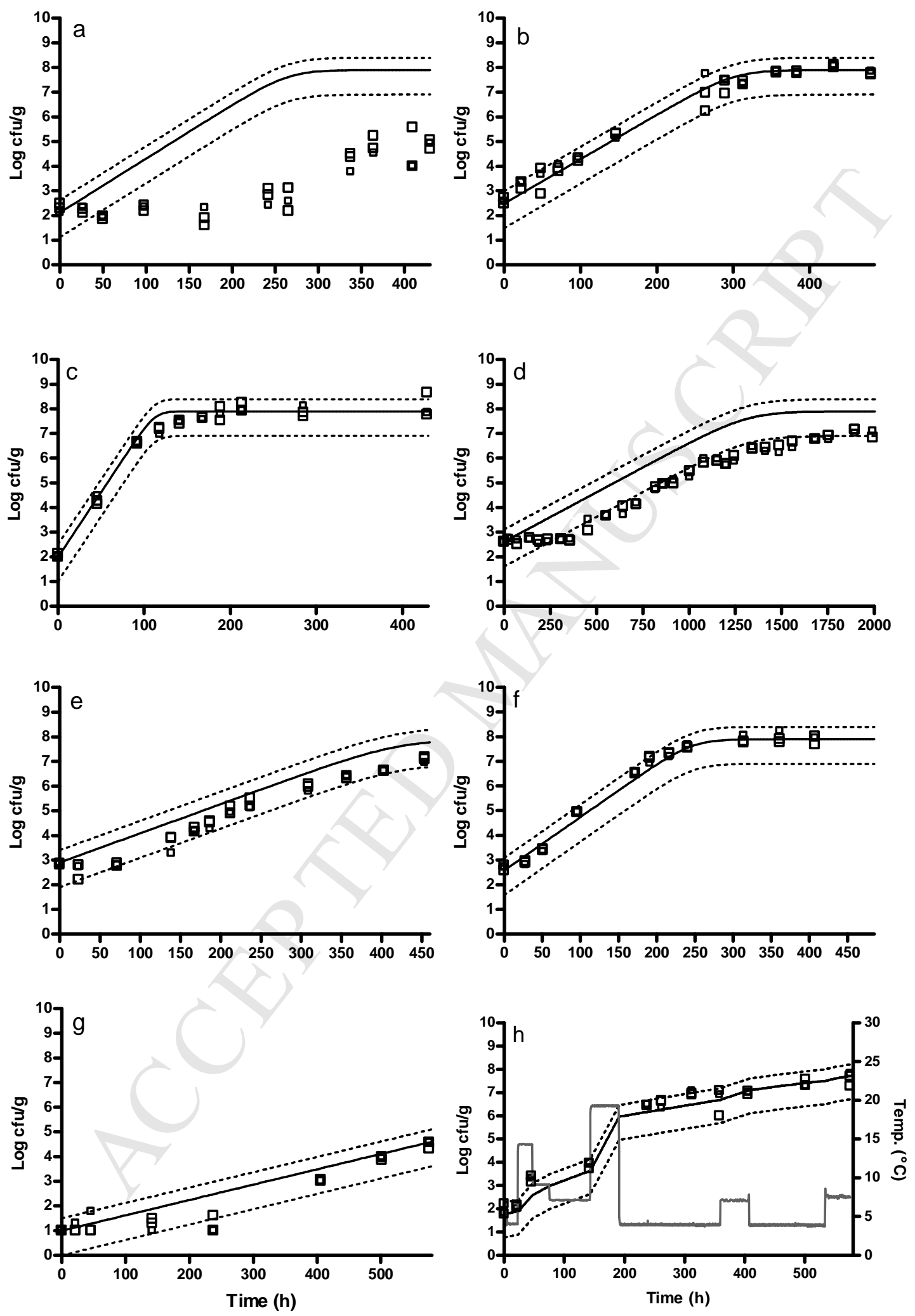
Fig.3. Comparison of observed ( $\square$ ) and predicted (-) growth of L. monocytogenes. Spreadable processed spread cheese was studied at $22.0 \pm 0.2^{\circ} \mathrm{C}$ (a), $4.8 \pm 0.4^{\circ} \mathrm{C}$ (b), $10.1 \pm 0.2^{\circ} \mathrm{C}$ (c), $14.5 \pm 0.2^{\circ} \mathrm{C}$ (d), $14.9 \pm 0.2^{\circ} \mathrm{C}(\mathrm{e}), 14.9 \pm 0.2$ (f), $7.2 \pm 0.2$ (g) and dynamic storage temperature $3.8-19.4^{\circ} \mathrm{C}(\mathrm{h}$, temperature profile is shown as grey lines). Solid lines represent the predicted growth by eq. (4) when using $\operatorname{MIC}_{C A C_{U}}(\mathrm{mM})$. Graphs include the ASZ (+0.5 and $-1.0 \mathrm{Log}$ cfu/g, dashed lines). 


\section{Highlights}

- Model to predict growth of Listeria monocytogenes in spreadable processed cheese

- Model including the effect of nine environmental factors

- Support tool for product development/reformulation of spreadable processed cheese 
Conflict of interest: Elissavet Gkogka is employed by Arla Foods 